\section{HIV/AIDS: key lessons for a successful response and for future challenges $^{1}$}

Key words: HIV, AIDS, antiretrovirals, health economics, health systems and services.

\footnotetext{
Based on: United Nations, General Assembly. Special session of the General Assembly on HIV/AIDS: report of the Secretary-General. New York: UN; 2001. Available from: http://www.un.org/ga/ aids/. Accessed 28 April 2001.
}

Concerned about the accelerating HIV/AIDS epidemic and its global impact, the United Nations General Assembly will hold a special session to focus on the disease from 25 to 27 June 2001 in New York City. The objective of the meeting is to intensify international action to fight the epidemic and to mobilize the needed resources.

At the special session national delegations will discuss what action plans have proven most effective in addressing the HIV/AIDS situation in their own countries and what steps are next needed. Interactive roundtable sessions will bring together government leaders, AIDS activists and experts, and private sector representatives to focus on key issues.

In preparation for that meeting, in mid-February UN Secretary-General Kofi Annan issued a document entitled Special Session of the General Assembly on HIV/AIDS: Report of the Secretary-General. The document examines the spread of the HIV/AIDS epidemic and its demographic, social, and economic impacts. The report also outlines key lessons learned about the elements of a successful response to the epidemic as well as challenges for an expanded response to HIV / AIDS. The document particularly emphasizes three concerns in the response to the epidemic: leadership, coordination, and the need for adequate resources.

The materials below summarize the sections of the report dealing with lessons learned and future challenges.

\section{KEY LESSONS LEARNED}

A successful response to HIV/AIDS incorporates several key principles, according to the Secretary-General's report. Among these are:

- that gender inequalities fuelling the epidemic must be explicitly addressed

- that prevention methods, life-saving treatments, and the results of scientific breakthroughs in prevention and care must be made broadly available, on an equitable and affordable basis to all

- that people living with and affected by HIV/ AIDS must be actively engaged and supported in their efforts to address the epidemic

- that national governments, working with civil society, must provide the leadership and means 
to ensure that national and international efforts respond to country and community needs

\section{Successful responses respect human rights}

Many human rights concerns must be addressed in order to combat stigma and eliminate discrimination based on HIV status. In addition to discrimination against HIV-infected persons, other important issues include the right to health care, the right to information, and other social and economic rights contained in United Nations human rights conventions and the Universal Declaration of $\mathrm{Hu}-$ man Rights. International guidelines on HIV / AIDS and human rights are key to a response based on human rights, and governments should continue their efforts to implement them.

\section{A broader epidemic can be prevented}

Reducing the rate of HIV infections pays substantial dividends. In many settings, large-scale prevention programs have demonstrated that the spread of HIV can be reduced, especially among young people. Prevention programs have also been successful among hard-to-reach populations, such as through harm reduction among injecting drug users.

\section{National efforts require leadership and multiple actors}

One of the key lessons learned from countries that have successfully responded to the epidemic has been the critical role of government and civil society leadership in increasing the visibility of the epidemic while decreasing the stigma associated with it. In more and more nations, partnerships have brought together the government, the international community, activists, people living with HIV/AIDS, nongovernmental organizations (NGOs), community-based organizations, religious and academic institutions, and the private sector.

Single, isolated activities do not yield sustained results. Interventions to reduce HIV risk and to encourage behavior change are effective when a range of government ministries and partners in the social, economic, and health sectors work together to provide an enabling environment for large-scale prevention, care, and support programs. Effective programs require focused action, steadily expanding coverage, and the involvement of the target population and of people living with HIV/AIDS in the design and implementation of interventions.

\section{Prevention works}

Intensive information and education programs are essential in reducing the risk of sexual transmission in the general population and in helping promote safer sexual behavior, such as through abstinence, fidelity, and condom use. The social marketing of both male and female condoms increases their accessibility. Voluntary HIV counseling and testing can serve as a critical entry point for HIV care and prevention. Interventions should specifically address the needs of young people before they become sexually active.

One particularly effective intervention is the prevention of mother-to-child transmission. A onemonth course of antiretroviral treatment given to HIV-infected mothers late in pregnancy can cut transmission to children by $20 \%$ to $50 \%$.

\section{Care and treatment should be comprehensive}

Treating and caring for people living with HIV/AIDS requires a comprehensive approach. This includes support for home- and communitybased care as well as equitable access to medical treatment, including drugs for opportunistic infections and antiretroviral therapy.

Medical care in high-income countries has extended the lives of people living with HIV. The challenge now is to improve access to care in developing countries as well, where the vast majority of HIV-infected people live. Brazil and other countries have developed effective, comprehensive programs that include such components as voluntary counseling and testing, psychosocial support, good nutrition, strengthening of the health system so as to ensure access, the prevention and treatment of opportunistic infections, and antiretroviral therapy. Although not yet available to all persons who need them, these programs provide an important model for expansion.

\section{Successful responses have their roots in the community}

Effective community-centered efforts have generally achieved two, complementary goals: strengthening the community's capacity to make decisions and assisting the community to mobilize the resources needed to act on those decisions. Knowledgeable community leaders are better able to assess the reality of HIV/AIDS within their community, analyze the determining factors of risk and vulnerability, and determine the priorities for action. 
Successful efforts to address HIV / AIDS at the community level require the development of partnerships that mobilize local responses, access national resources, and strengthen the awareness and capacity of the various stakeholders. Such partnerships will likely include key social groups, government service providers, NGOs, people living with HIV / AIDS, community-based groups, and religious organizations.

\section{Empowering young people is essential}

Special efforts must focus on the needs of young people. Sexually active adolescents require special family planning information counseling and health services as well as treatment for sexually transmitted diseases (STDs). Appropriate education and services can help prevent the transmission of STDs and HIV. Government legislation and other measures can ensure that young people and other vulnerable populations can obtain the information they need to prevent further disease transmission and are able to access treatment and care services without stigmatization, discrimination, or violence.

\section{People living with HIV/AIDS are central to the response}

One of the best ways to give AIDS a "human face" is through the greater involvement of people living with HIV/AIDS. Persons who live with or are directly affected by the disease can bring their personal experience to planning and carrying out a response to the epidemic, broaden the dialogue concerning HIV/AIDS, challenge complacency and denial, strengthen the call for urgency in the response, and move governments and their leaders to action.

\section{The response must deal simultaneously with risks, vulnerability, and impact}

The epidemic is dynamic and involves relationships among three key elements: specific risks, made up of behaviors and situations that might promote the transmission of HIV; vulnerability, that is, factors that make it more likely that some individuals become infected, such as being a poor woman or a migrant; and impact, the consequences of the epidemic for individuals and communities. Effective long-term responses must address each of these elements, which can be different for men and women. Decreasing the risk of infection slows the epidemic. Decreasing vulnerability reduces the risk of infection and the impact of the epidemic. Decreasing the impact of the epidemic decreases vulnerability to HIV / AIDS.

Each setting requires a different focus and a different balance between these three elements, with regional and subregional strategies complementing and adding value to a national response.

\section{CHALLENGES FOR AN EXPANDED RESPONSE}

Broadening and deepening the current successful responses to the HIV/AIDS epidemic will necessitate overcoming a number of hurdles.

\section{Leadership and coordination}

Some have described the AIDS epidemic as a crisis of governance and a crisis of leadership. Leadership is vital if the nature of the epidemic is to be clearly understood throughout society. Leadership is also needed in order to have a national response that avoids fragmented efforts and that secures the full commitment, involvement, and accountability of all sectors.

\section{Alleviating the social and economic impact}

The epidemic's spread requires a multisectoral response that addresses both institutional capacity and human resources. In many countries, the epidemic has substantially undermined the performance of the labor force, the education sector, and the health sector, among others. Each sector needs support in a coordinated response to the epidemic, with assistance for poverty alleviation, infrastructure development, and education- and health-sector development.

Responding to the epidemic therefore requires effective measures to support risk reduction and reduce social and economic vulnerability. Strategies that systematically promote social inclusion extend access to information, essential services, and supportive legal and social norms and can reduce vulnerability and help overcome the impact of the epidemic.

\section{International efforts}

International efforts should include research on microbicides, vaccines, and HIV medicines that are more effective, accessible, and affordable. Ef- 
forts should also be made to develop and market female-controlled contraceptives.

\section{The cost of medicines}

Another key concern is the affordability of medicines for opportunistic infections and antiretroviral therapy. While progress has been made in reducing the price of medicines and in increasing the availability of generic versions of antiretroviral drugs, much more needs to be done in order to provide greater access to care and treatment for the majority of people living with HIV and AIDS.

These efforts must take into account relationships among pricing, financing, trade policy, and health care systems. A country's strategic plan for care must address the issue of equity and the use of public resources. The effective use of such trade policy provisions as compulsory licensing or parallel importation can increase access to care. The availability of low-cost generic drugs needs to be expanded, in accordance with national laws and international trade agreements and with guarantees of their quality. Other approaches also need to be explored, including tiered pricing, improved global and regional procurement policies, and new funding mechanisms.

\section{Resources}

In responding to the epidemic, greatly increased resources are needed to support essential infrastructure and training, to mitigate the social and economic impacts, to expand successful prevention interventions, and to implement a broad care agenda, including access to drugs. HIV / AIDS priorities need to be properly integrated into the mainstream of development planning, including poverty reduction strategies, public investment plans, and annual budget processes. Increased investment from donors, domestic budgets, and private companies and foundations will be necessary, along with funds released through debt relief.

At the United Nations General Assembly special session in June, governments are expected to agree on a Declaration of Commitment that will outline priority areas where stronger action must be taken. These are likely to include prevention, improved access to care and treatment, care of children orphaned by AIDS, expanded public/private sector partnerships, the need for an accelerated multisectoral response to the epidemic, and resources commensurate with the crisis.

\section{SINOPSIS}

\section{VIH/SIDA: lecciones esenciales para una respuesta eficaz y para afrontar futuros desafíos}

Movida por la rápida expansión de la epidemia de VIH/ SIDA y su impacto mundial, la Asamblea General de las Naciones Unidas convocará una reunión especial en Nueva York en junio de 2001 para examinar la situación de la enfermedad. Como parte de los preparativos para la reunión, el Secretario General de las Naciones Unidas, Kofi Annan, emitió en febrero de 2001 un documento titulado Reunión Especial de la Asamblea General para tratar el tema del VIH y el SIDA: informe del Secretario General. En el documento se examinan la propagación de la epidemia de $V I H / S I D A$ y su impacto en términos demográficos, sociales y económicos. También se detallan las lecciones esenciales que se han aprendido sobre las características de una respuesta eficaz contra la epidemia, y sobre las dificultades de intensificar esa respuesta. He aquí algunas de las lecciones presentadas en el documento: las respuestas eficaces muestran un respeto por los derechos humanos; se puede prevenir la expansión de la epidemia; las iniciativas nacionales requieren dirección y la participación de una variedad de actores; las medidas de prevención son eficaces; la atención y el tratamiento deben ser integrales; las buenas respuestas se arraigan en el seno de la comunidad; es esencial empoderar a la juventud; las personas que viven con el VIH y el SIDA desempeñan un papel central en las medidas de respuesta, que deben tener en cuenta simultáneamente los factores de riesgo, la vulnerabilidad del paciente y el impacto de la enfermedad. Para poder incrementar el alcance y la profundidad de las respuestas que actualmente están surtiendo buenos resultados, habrá que superar una serie de dificultades, entre ellas las de proporcionar liderazgo y coordinación, mitigar el impacto social y económico de la epidemia, lanzar iniciativas internacionales, afrontar el costo de los medicamentos y destinar los recursos necesarios. 